\title{
Wind control on the accumulation of heavy metals in sediment of Lake Ulubat, Anatolia, Turkey
}

Kazancı N. ${ }^{1 *}$, Leroy S. A. G. ${ }^{2}$, Öncel S..$^{3}$, İleri Ö..$^{4}$, Toprak $\ddot{O}^{3}$, Costa P. ${ }^{2 \propto}$, Sayılı S. ${ }^{1}$, Turgut C. ${ }^{3}$, Kibar M.

1 Department of Geological Engineering, Ankara University 06100 Beşevler, Ankara, Turkey (kazanci@eng.ankara.edu.tr) (sayili@eng.ankara.edu.tr)

2 Institute for the Environment, Brunel University, Uxbridge, UB8 3PH (West London), UK (Suzanne.leroy@brunel.ac.uk)

3 Gebze Institute of Technology, 41400 Gebze, Kocaeli, Turkey (soncel@gyte.edu.tr) (ozlemtoprak34@yahoo.com)

4 General Directorate of Mineral Research and Exploration, 06520, Ankara, Turkey (ozden@mta.gov.tr)

5 Ankara University, Faculty of Agriculture, Department of Soil Sciences, 06100 Dışkapı Ankara, Turkey (mkibar@agri Ankara.edu.tr)

Keywords: Lake Ulubat, Heavy metal, Wind effect, Holocene, Turkey

\footnotetext{
* Corresponding author, E-mail: Nizamettin.Kazanci@eng.ankara.edu.tr

${ }^{\propto}$ Present address: Departamento de Geologia, Universidade de Lisboa, Portugal(ppcosta@fc.ul.pt)
} 


\section{Abstract}

Freshwater Lake Ulubat $\left(\mathrm{z}_{\text {mean }}=1.5-2.0 \mathrm{~m}\right.$ and Area $\left.=\sim 138 \mathrm{~km}^{2}\right)$, NW Anatolia, Turkey was filled in by fine-to-medium-grain silts during the late Holocene. Deposition in Lake Ulubat has been $1.6 \mathrm{~cm} \mathrm{yr}^{-1}$ for the last 50 years, but the sedimentation rate over the last $\sim 1,600$ years was lower $\left(0.37 \mathrm{~mm} \mathrm{yr}^{-1}\right)$. The organic matter and carbonate contents of the infill show cyclic changes that reflect environmental fluctuations. The silt-dominated lithology and the vertically uniform heavy metal distributions are probably due to wind-controlled sedimentation in the lake. Heterogeneous mud, derived from a large, mountainous drainage basin, is deposited in the lake mostly during summer, June to October, when conditions are hot and calm. Winter months are stormier and sediments are re-suspended due to the shallow water depth and the effect of waves on the lake bottom. It is likely that re-suspended sediments, particularly fine-grained particles, together with the heavy metals, are transported out of the lake via the outlet, especially during periods of high lake level. This resuspension and removal process probably caused the lake sediments to become silt-dominated and depleted in heavy metals. The role of broad shallow lakes in sequestering sediments and heavy metals can be described more accurately when wind data are considered. Such information may also be helpful for land-use planning in downstream areas. 


\section{Introduction}

Lake Ulubat (Apolyont or Uluabat) is a shallow, partly polluted, fresh-water body in northwest Anatolia, Turkey (Fig. 1). Presently this lake is an important recreational area for the town of Bursa, which is the largest settlement in the region (Fig. 1). Water discharged from the lake outlet is crucial for both agriculture and domestic use in the southern Marmara region. Monitoring of rivers over the last 50 years indicates that large quantities of sediment and pollutants, mostly heavy metals, have been transported to Lake Ulubat (EIE 1996, 2000, 2003). In short, the lake water has been affected by natural and anthropogenic activities. Recent studies, however, show that Lake Ulubat is oligotrophic despite sediment infilling and pollution (Kazanc1 et al. 1998; Çelenli 2000). Understanding how the lake has maintained its oligotrophic condition could provide new insights for palaeolimnological reconstructions and for land-use planning of downstream areas.

The heavy metals discussed in this study, $\mathrm{Ba}, \mathrm{Cd}, \mathrm{Co}, \mathrm{Cu}, \mathrm{Fe}, \mathrm{Hg}, \mathrm{Mn}, \mathrm{Ni}, \mathrm{Pb}, \mathrm{Sr}$, are generally found in lake sediment as trace elements. Very small amounts are required by living organisms, particularly mammals. Except for Fe, high doses are toxic and these elements are therefore considered pollutants (Ek and Renberg 2001). In modern environments they come, sometimes in large quantities, from industrial or other anthropogenic sources (Larsen 2000; Çiçek and Koparal 2004; Blake et al. 2007). Heavy metals are rare in the earth's crust, although they are more abundant in magmatic and metamorphic rocks than in sedimentary ones; hence they can recycle naturally from source rocks by weathering (Boyle 2001). So, in some cases, heavy metals in sedimentary rocks are used as tools for provenance studies (Engstrom and Wright 1984; Bilali et al. 2002). They can be found as cations or elements in both water and fine sediments, and also in heavy minerals like ilmenite, rutile and zircon in sandy sediment (e.g. in alluvium or sand dunes), or as trace elements in minerals (e.g. Cu in colemanite). Lakes, open or closed, are unique environments for heavy metals to accumulate within fine-grained sediments. This accumulation is controlled by factors such as climate, limnological characteristics, the presence and amount of organic matter and type of source rocks (Last and Smol 2001; Hoffman et al. 2005). There has been, however, no demonstrated direct relation between climate and the accumulation of heavy metals. It is possible that local properties, acting individually or together, e.g. water level oscillations, wind stress, or water depth, have reduced the role of climate on heavy metal deposition in lakes. Establishing the role of wind on the deposition of metal ions in lacustrine records could be very useful for both reconstructing palaeo-environments and managing water reservoirs. Some models of heavy metal deposition in shallow lakes show that 
metal accumulation is controlled predominantly by circulation of the lake water (Blom et al.1992; Mian and Yanful 2004). The southern Marmara region, which includes the study site, is one of the windiest areas of Turkey, hence it has a large wind-energy potential (Dündar et al. 2002). Moreover, short and long-term climatic changes, especially dry and wet periods in this region during the last millennia, are relatively well known from historical, archaeological and paleolimnological studies (Kuniholm 1990; Vermoere et al. 2002).

This study presents the heavy metal content of Lake Ulubat and explores the factors that control the elemental composition of the lake sediment. It also addresses the possible link between sediment and metal deposition rate and wind. For this study, both the sediment (modern and ancient) and the water of Lake Ulubat were studied (Fig. 2). In addition, water circulation in the lake was simulated by tank experiments. Lake Ulubat is suitable for such a study, as the environmental characteristics of this lake and possible sources of pollutants are known from previous studies (Çelenli 2000; Toprak 2004; Turgut 2005; Dalkıran et al. 2006). The late Holocene erosion and the morphological evolution of this region have been interpreted based on sedimentation rates and modern sediment loads in Lakes Ulubat and Manyas (the latter is a few $\mathrm{km}$ west of L. Ulubat), and in the shelf of the Marmara Sea (Kazanc1 et al. 2004; 2006). Moreover, pollen assemblages within sediment sequences of the same lakes have been used to study the past vegetation and climate of the area (Bottema et al. 2001; Leroy et al. 2002). Lastly, understanding pollutant behaviours, e.g. the sinking and the remobilisation of heavy metals, is an increasingly important topic in the planning of lake rehabilitation and protection of aquatic environments.

\section{Geologic and geographic setting}

The northwest Anatolian region of Turkey comprises the whole southern Marmara region known as the "Susurluk Drainage Basin" (SDB) (Fig. 1B). It has a fresh morphology with some high topography due to neotectonism since the Neogene. Lake Ulubat is located on the eastern side of a large W-E tectonic depression formed at the transition of the transform North Anatolian Fault (NAF) zone and the extensional tectonic regime of western Anatolia (Emre et al. 1997a, 1998) (Fig. 1A). This Manyas-Karacabey depression is tilted towards the east where Lake Ulubat is found, and it controls the drainage of an important part of the SDB (Fig. 1). The geological origin of this lake is still uncertain, but it is thought that it began with the damming of a meandering stream system, possibly during a period of mid-Holocene sea level increase (Emre et al. 1997b; Leroy et al. 2002). 
The stratigraphy of the SDB is fairly complex, and various rocks are exposed (Yilmaz et al. 1990; Okay et al. 1991; Görür et al. 1995). Volcanics, clastic sedimentary rocks, clayey limestones and evaporites of Late Tertiary age and, to a lesser extent, older metamorphic rocks outcrop in the higher parts of this region (Yalçınkaya and Avşar 1980; Görür et al. 1995). However, collated borehole data have established that the lake is partly surrounded by large areas of Holocene alluvial deposits and by Pleistocene fluviatiles in the lower parts of the drainage basin (Kazanc1 et al. 1997, 1998). Lake Ulubat, however, is closely bounded by karstified limestones of Mesozoic age in the east. Sedimentary and volcani-sedimentary rocks of Neogene age, mostly Miocene, form extensive units in the drainage area. Most of the Neogene rocks in the south are composed of volcaniclastics, lacustrine limestones and intercalations of tuffs, lava flows and marl layers (Helvacı and Firman 1977; Yalçınkaya and Avşar 1980; Akyüz and Semiz 1995). These units include the well-known borate beds of Turkey (Fig. 1), hosted into a lacustrine succession with volcanic intercalation. They provide the heavy metal content to Lake Ulubat's sediment, owing to a well-developed river-drainage system. The famous Paşalar site of the Miocene, which has yielded hominoid bones, is also part of the SDB (Andrews 1990).

The main rivers of SDB are the Kocaçay River $(162 \mathrm{~km})$, the Simav/Susurluk River (321 $\mathrm{km})$, the Emet River $(278 \mathrm{~km})$, the Orhaneli River $(276 \mathrm{~km})$ and the Nilüfer River $(172 \mathrm{~km})($ Fig. 1B). The rivers Emet and Orhaneli form the River Mustafakemalpaşa (MKP) by merging $45 \mathrm{~km}$ south of Lake Ulubat. The rivers Simav, Kocaçay and Nilüfer join near the town of Karacabey and form the River Kocasu just before discharging into the Sea of Marmara (Fig. 1). Two active boron mines, one on the Emet River (Etibank Emet Bor Işletmesi), and the other on the Orhaneli River (Etibank Kestelek Bor Işletmesi), and three lignite industries on the Orhaneli River (TKI Keles Linyit Işletmesi, TKI Tunçbilek Garb Linyitleri Işletmesi, TEAŞ Tunçbilek Thermal power plant) produce a good deal of sediment and pollutants that drain into the lake and sea (EIE 1996, 2000). The prominent mountains of the southern Marmara region are Uludağ $(2543 \mathrm{~m})$ to the north, Akdağ $(2089 \mathrm{~m})$ to the centre in the south, and Şaphanedağ $(2120 \mathrm{~m})$ to the southsoutheast (Fig. 1B,C). 


\section{Local and regional climate}

The climate of the SDB is continental in its southern part and eu-Mediterranean in the north. The local topography and the distance from the sea are a source of local climatic diversity. Based on a 70-year-long record from the meteorological station nearest to Lake Ulubat and its drainage basin (Karacabey, at the western end of L. Ulubat, Fig. 1C), annual mean temperatures are 14.4 ${ }^{\circ} \mathrm{C}$, with mean August temperatures of $24.0^{\circ} \mathrm{C}$ and mean January temperatures of $5.5{ }^{\circ} \mathrm{C}$. The annual mean precipitation is $593.9 \mathrm{~mm}$, with a November mean of $103.9 \mathrm{~mm}$ and a July mean of $14 \mathrm{~mm}$ (Table 1).

Wind has an important role in the climate of the Marmara region (Fig. 1C). Storms occur mainly in winter and spring. The northeasterly cool wind (Poyraz in Turkish) has a much greater effect (from December until April) upon the regional weather than does the southwesterly mild wind (Lodos in Turkish), which blows generally from April to June (Fig. 1C). The cold winds form $60 \%$ of the annual winds in the region. Rain is associated with both cold and mild winds. The mean, median and maximum wind speeds at $10 \mathrm{~m}$ above ground surface are 2.7, 4.4 and 17.0 m/s, respectively (Koçman 1993; Özdemir and Kırmızıgül 1997). The western part of the Karacabey-Manyas depression, however, is relatively windier. The mean speeds of weak, medium-strength and strong winds in this area are 4,8 and $25 \mathrm{~m} / \mathrm{s}$, respectively. Winds from $30^{\circ}$ $\mathrm{NE}$ accounted for $60 \%$ of the winds in a year, according to the records of the Bandirma (on the Marmara coast, north of Ulubat) and Karacabey meteorological stations, over the last 70 years (Özdemir and Kırmızigül 1996) (Fig. 1C). The maximum wind speeds in the four large towns of the region (Bursa, Bandırma, Balıkesir and Çanakkale) for the period 1975 to 2005 were 30.7, 32.8, 29.3 and $38.7 \mathrm{~m} / \mathrm{s}$, respectively (www.meteoroloji.gov.tr). The number of stormy days with medium-strength winds in these towns is 15.2-17.3 (Dündar et al. 2002). Local morphological features, i.e. the presence of large water surfaces (the Black Sea and the Marmara Sea) and wind passages (İstanbul Boğazı-Bosphorous, Çanakkale Boğazı-Dardanelles, particularly the Karacabey Gorge, which houses the River Kocasu and the outlet of Lake Ulubat) amplify the effects of wind, and thus this region is much windier than its surrounding areas. As a result, one of the climatic characteristics of the area is a windy winter and spring. 


\section{Lake Ulubat}

Lake Ulubat has a maximum water depth of $3.5 \mathrm{~m}$. The average water depth is $1.5 \mathrm{~m}$ in summer and $2.0 \mathrm{~m}$ in winter, even though the annual fluctuations of the water level have been controlled since 1990 (Fig. 3). The lake surface area is $\sim 138 \mathrm{~km}^{2}$ according to the Landsat TM images of May 1998, but only 119 and $105 \mathrm{~km}^{2}$ according to the Landsat ETM of July 2000 and 2007, respectively (Fig. 2), in accordance with a rapid surface reduction as the delta progrades (database; http://glcfapp.umiacs.umd.edu:8080/esdi/index.jsp). The sediment load and water chemistry of the rivers flowing into Lake Ulubat and lakes in the SDB have been monitored since 1935 by a state institute, the EIE, as the lake is very important for the economy and daily life of the 17 villages in its vicinity. Most of the limnological properties of Lake Ulubat have been established in previous studies (Kazancı et al. 1998; Çelenli 2000; Turgut 2005). The water surface of the lake is only $2 \mathrm{~m}$ above sea level; however the distance is ca. $23 \mathrm{~km}$ from the Marmara Sea along the lake outlet, via the Karacabey gorge. It is an open, oligotrophic, freshwater lake with an elongated shape (23 km long E-W and $12 \mathrm{~km}$ wide N-S). The periphery of the lake is irregular owing to fault scarps in the SE, old karstic features in the NE, and delta progradation in the SW. Four islands of Mesozoic limestones delineate the two main sub-basins called the Western Basin and the Eastern Basin that influence water and sediment circulation (Fig. 2). Other islands consist of sediment deposited after the formation of the lake. The main water and sediment source of Lake Ulubat is the MKP River that has an overall drainage area of ca. $10,414 \mathrm{~km}^{2}$. Its mean, minimum and maximum water discharges are $64,7.5$ and $3,374 \mathrm{~m}^{3} / \mathrm{s}$, respectively (EIE 2000). The suspended sediment load of the MKP River has averaged about 1.3 $\mathrm{x} 10^{6}$ ton $\mathrm{yr}^{-1}$ in the last 30 years, leading to a linear sedimentation rate of $1.6 \mathrm{~cm} \mathrm{yr}^{-1}$, established by radionuclide analyses (Kazanc1 et al. 2004).

The delta of this river rapidly progrades into the lake from the SW to the NE and it has shifted towards the southeast, probably under tectonic control (Figs. 1 and 2). In summer, the lake level falls to below the bottom of the outlet due to minimum discharge from the MKP River and extensive water pumping from the lake for agricultural use. Active boron and lignite mines, a thermal power plant, borate-bearing rocks, and some hydrothermal springs in the drainage area cause an increase in the content of boron and other heavy metal ions of the lake water (Çelenli 2000; Dalkıran et al. 2006). Boron content and water quality of the inflow and outflow lake water have been monitored by EIE observatories (stations no 302 and 317; Figs. 1, 5).

Annual (natural) oscillations of water level are common in Lake Ulubat. Moreover, its mean water level changes by 1.5 to $2.0 \mathrm{~m}$ with a periodicity of $8-11$ years (Fig. 3). This periodic 
change represents the relatively dry and wet periods of the Mediterranean Anatolian climate (Özdemir and Kırmızıgül 1997).

\section{Methods}

Because our study methods and analytical results have been detailed previously (Leroy et al. 2002; Kazanc1 et al. 2004, 2006), only a short summary is given here. Limnological characteristics of Lake Ulubat were first reported based on sampling completed in 1997. Sampling was conducted again in 2002 and 2004 (Kazanc1 et al. 1998, 2006; Toprak 2004; Turgut 2005). The water content of the lake sediment was detected in the first survey by the stick-pushing method (Suliman 1998). In 2002, together with studies of water chemistry, a coring campaign was conducted using 63-mm-diameter PVC pipes and a hand-pushed Livingstone piston corer (50-mm-diameter). The corers were operated from a raft, and we retrieved a suite of sediment cores in $1 \mathrm{~m}$ sections at eleven sites. Cores were labelled for the year of collection, "AK02." The longest core, which reached a depth of $7.8 \mathrm{~m}$, was collected at the centre of the eastern basin of the lake (Fig. 2). Sampling at stations 1 to 5 was done by 2-m-long PVC pipes (AK02PVC 1-5), and at the others (AK02LV 6-11) by the Livingstone corer (Kazanc1 et al. 2006). The results presented in this study are from detailed analyses of the first seven metres of core AK02LV10 (length: $7.35 \mathrm{~m}$ ) and from AK02LV12 (length: $7.80 \mathrm{~m}$ ), taken at station 11 near the delta front, and of core AK02PVC4 (length: $1.90 \mathrm{~m}$ ), from station 2, far from the delta and near the village of Gölyazı (Fig. 2). Water samples were taken at $0-10 \mathrm{~cm}$ below the lake surface (20 samples) and bottom samples by Hydrobios bottles at each coring station (6 samples) in 2002 (Fig. 2). In 2004, a second coring campaign concentrated on the centre of the eastern basin, and cores were collected from depths of 6 to $9.7 \mathrm{~m}$. That year, the cores were labeled "AK04." Just before this coring campaign, in the third week of May, the lake water was re-sampled. In order to check the heavy metal distribution in the lake, 28 water samples were collected from different parts of the lake (Fig. 2). pH, dissolved oxygen and conductivity of the lake were also measured at sites using an OXI33OI set from the Gebze Institut of Technology, in both 2002 and 2004.

The water chemistry and the suspended sediment load of rivers in the SDB were regularly monitored by a state office (EIE). Furthermore, long-term water quality surveys of the lake outlet and the MKP River by the EIE at stations 302 and 317 were evaluated for comparison (EIE 2003; Figs. 1 and 5).

Loss-on-Ignition data were obtained by the combustion of $5-\mathrm{cm}^{3}$ sediment samples in a furnace at 550 and $950{ }^{\circ} \mathrm{C}$. Percentages were calculated relative to the dry sediment, with organic 
matter, carbonate and residual ash forming 100\%. The mineralogy of the sediment was determined by optical, XRD and XRF analyses. Grain-size analysis was done on samples at 7-10 $\mathrm{cm}$ intervals (1-2 cm intervals in AK02PVC4 [Fig. 4B]) using an automatic grain-size analyser with a laser (Malvern Instruments, Mastersizer model 2000), and Griffith's (1967) terminology and description were used for statistical calculation and interpretation. The heavy metal content of the lacustrine sediments (cores AK02LV10, AK02PVC4 and surface samples) was measured by the method of AAS with a graphite furnace, using the Perkin Elmer Simaa 6000 instrument (Fig. 7). The elements $\mathrm{Al}, \mathrm{Ba}, \mathrm{Cd}, \mathrm{Co}, \mathrm{Cu}, \mathrm{Fe}, \mathrm{Hg}, \mathrm{Mn}, \mathrm{Ni}, \mathrm{Pb}$ and $\mathrm{Sr}$ were chosen for their abundance in parent rocks and the analytical facilities in our laboratories. For analyses, samples were first dried and ground and then treated with a series of acids: $2 \mathrm{ml} \mathrm{H}_{2} \mathrm{SO}_{4}+2 \mathrm{ml} \mathrm{HNO}_{3}+$ $0.5 \mathrm{ml} \mathrm{HF}+1 \mathrm{ml} \mathrm{HCl}$. Later, additional samples were dissolved with the help of an ETHOS 1600 microwave. Analytical results are displayed together with organic matter and carbonate content, mean grain-size, As, and boron content (Fig. 7). Psimpoll 4.10 was used to plot the data (Fig. 8) as well as for statistical analysis (Bennett 2003).

A tank experiment was designed to assess the wind effect on the transport of suspended sediment in standing water. This was accomplished using a plastic tank $(100 \times 50 \times 10 \mathrm{~cm})$ for water and an adjustable fan as a wave generator (air dryer; Roveling CV 4015 of Roventa). A sediment sample composed of $20 \%$ sand $(125-250 \mu \mathrm{m}), 40 \%$ silt $(>10 \mu \mathrm{m})$ and $40 \%$ clay $(<4$ $\mu \mathrm{m})$ was used for the experiments. This grain size distribution is not exactly the same as that in the cores, but is similar (Fig. 4). The experiments were realized using sediment samples of 0.5 $\mathrm{kg}, 1 \mathrm{~kg}$ and $1.5 \mathrm{~kg}$ individually at different water levels (i.e. water depths of $2 \mathrm{~cm}, 4 \mathrm{~cm}$ and 5 $\mathrm{cm}$ ), and hence the experiments were repeated nine times. Before testing, $100 \mathrm{~g}$ calgon was added to each wet sample and the samples were shaken for 12 hours to prevent flocculation. For testing, the watery sediment was poured into the tank, which was filled with water to a specified depth of 2, 4 or $5 \mathrm{~cm}$. There were rectangular holes $2-\mathrm{cm}$ wide and 1-cm high at these heights on the narrow side of the tank, for outflow, to simulate the outlet of Lake Ulubat. The sediment sample was left for 3 hours to permit clay-size particles to settle. Then the clean water was allowed to flow into the tank from taps, with a constant discharge of $0.02 \mathrm{litre} / \mathrm{s}$. This is proportional to discharge of the MKP River. Next, waves were generated by the fan with a speed of $300 \mathrm{rpm}$, and they were allowed to affect the sediment surface; however, water continued to flow for 3 hours. During this time, the fan was $25 \mathrm{~cm}$ away from the tank and it was opearted three times for ten-minute periods in each experiment. At the end of each experiment, the grainsize of the sediment remaining in the tank was measured with a Malvern Mastersizer 2000.

The experiment was designed to show the effect of waves on the winnowing of suspended particles. Sediment concentrations, water depth and wave strength were secondary to the study. 
They were chosen to generally simulate the environmental conditions of Lake Ulubat. We note that during the experiments, we did not generate regular surface waves, but instead caused the water in the tank to "vibrate." This was a limitation of the equipment, particularly the small tank size. Nevertheless, particles were suspended and transported in the "vibrated water".

\section{Results}

Heavy metals in modern lake water

Water quality and heavy metal concentrations have been measured in Lake Ulubat as part of several studies and were monitored on a monthly basis for a long time by the Directorate of State Electricity Works (EİE). Results varied depending on month, season and year (EİE 1996). The measurements for this study were completed in July 2002 and May 2004 (Tables 2 and 3). The interpretation of these data with respect to water quality has been reported elsewhere (Toprak 2004; Turgut 2005).

The $\mathrm{pH}$, dissolved oxygen (DO) and conductivity values of the modern lake water fall in the ranges 8.2-9.2, 3.8-6.5 mg/l, and 475-637 $\mu \mathrm{S} / \mathrm{cm}$, respectively. The $\mathrm{HCO}_{3}$ content varies from 80 to $200 \mathrm{ppm}$. Long-term water chemistry and water discharges into the lake show that boron was the dominant element entering the lake via the Emet River, particularly in summer (EIE 1996). Despite the limited water discharge at that time, opencast mining is intense in the drainage area (Kazanc1 et al. 2006).

The dominant elements in the lake are $\mathrm{Al}, \mathrm{Fe}$ and $\mathrm{Ba}$. The range of $\mathrm{Ba}$ is $1.20-2.36 \mathrm{ppm}, \mathrm{Al}$ is 0.2-39 ppm, and $\mathrm{Fe}$ is 2-138 ppm (Table 2; Fig. 6). $\mathrm{Hg}$ and $\mathrm{Cd}$ are the rarest elements, with values of 0.19-0.88 ppb and 0.01-0.56 ppb, respectively. Concentrations for $\mathrm{Ni}, \mathrm{Cr}, \mathrm{Cu}$ and $\mathrm{Mn}$ are $12.51,4.31,2.83$ and $2.17 \mathrm{ppb}$, respectively (Table 2, Fig. 6). Present heavy metal concentrations indicate that Lake Ulubat falls into water class III (polluted water) and water class IV (very polluted water), according to international standards (EPA 1973). The spatial distributions of the elements, however, are not homogenous in the lake (Fig. 6). $\mathrm{Cd}, \mathrm{Pb}, \mathrm{Ni}, \mathrm{Cu}$ and $\mathrm{Mn}$ are more abundant in the eastern basin, whilst $\mathrm{Hg}, \mathrm{Cr}, \mathrm{Ba}, \mathrm{Al}$, and $\mathrm{Fe}$ concentrations are greater in the western basin of the lake. $\mathrm{Fe}, \mathrm{Al}$ and $\mathrm{As}$ are relatively abundant at the mouth of the MKP River (Turgut 2005). Maps of the heavy metal distributions in the lake water and the monthly discharges into the lake show the importance of combined fluvial and melt water input 
(Figs. 5 and 6). The annual ranges of minimum and maximum values were typically large in 2002, probably due to a less windy July (Table 2). In addition, heavy metal concentrations are high in and around villages (e.g. Gölyazı and Ulubat) and in lacustrine areas covered by reeds, particularly in the eastern basin near the delta margins (Figs. 2 and 6; Tables 2 and 3). This is probably due to the restriction of water circulation by aquatic plants. Winds also create greater water circulation in the western basin than in the eastern basin because of the wind direction and the location of the outlet. The mean concentrations of heavy metals in the lake measured in 2004 are, however, equal to or less than those of the MKP River (Table 2). This may be a consequence of the lake's large outlet, which promotes rapid flushing of the lake water, i.e. short residence time. A high amount of boron in the Kocasu River outflow is recorded in July, August and September at EIE Station 317, due to intense opencast mining in summer (Fig. 5). The deposition time, however, is not known. As noted earlier, one of the main sources of heavy metals and boron in the southern shelf of the Sea of Marmara is the outlet from Lake Ulubat (Algan et al. 2004; Çağatay et al. 2004).

Heavy metal concentrations in the lake water display a difference between the surface and the bottom (Tables 2 and 3). Values are higher in bottom waters, in some places by as much as four times. This gradient is greatest in the eastern basin where aquatic plants are abundant (Table 3). So far, the differences in concentration of some metals, from bottom to surface waters in Lake Ulubat (Table 3), are not well understood.

\section{Heavy metals in modern lake sediment}

Samples taken with an Ekman-type dredge at 36 locations show that modern sediments of the lake consist of dark-coloured mud that smells of $\mathrm{H}_{2} \mathrm{~S}$ (Kazanc1 et al. 1998). It contains over $60 \%$ water. At a depth of around $30 \mathrm{~cm}$, the water content of the sediment decreases to $<55 \%$, and it becomes stiff mud. The upper $45 \mathrm{~cm}$ of the sediment sequence is 33-45 years old according to radiometric dating (Kazanc1 et al. 2006). Hence, the uppermost $10 \mathrm{~cm}$ can be considered very recent sediment. The top $5 \mathrm{~cm}$ of core AK02LV10, the uppermost $3 \mathrm{~cm}$ of core AK02LV12, and the top $2.5 \mathrm{~cm}$ of core AK02PVC4 were analyzed for metal concentrations (Table 4). The concentrations of metals in the top of core AK02PVC4 are slightly higher than those at the top of core AK02LV10, probably because the former is much closer to the reed-covered lake margin and to Gölyazı village (Fig. 2). The concentration of each heavy metal in surface sediment 
$(\mathrm{mg} / \mathrm{kg})$ is larger than that of the lake water $(\mathrm{mg} / \mathrm{L})$ and also of the MKP River. However, metal concentrations in the surface sediments and deeper deposits are the same (Tables 2-4; Fig. 7).

The sediment sequence and its heavy metal content

Analyses of the first $7 \mathrm{~m}$ of Lake Ulubat's sediment infill are presented here. Radiometric dating and fossil correlation suggest that the sequence covers approximately the last 1600 years (Kazanc1 et al. 2006). Grain-size distribution, organic matter, and carbonate content of the sequences from core sections AK02PVC4/1-2 and AK02LV 10/1-11 are shown in Fig. 7. Siltsize particles dominate. Particles become slightly coarser $(15-60 \mu \mathrm{m})$ at greater depths in the sequence, particularly at depths of 7-6 m. The transition is not apparent visually.

The lithology of the pre-modern lacustrine sequence is typically a silty, plastic sediment with a grey colour (7.5YR 5/0 and 4/0, with slightly lighter zones of 5Y 5/1). Except for the uppermost slurry, the water content decreases toward the bottom of the sediment sequence, from 60 to $37 \%$. Grain-size analysis indicates dominance in the range of $10-35 \mu \mathrm{m}$. The volumetric ratios of sand, silt and clay along the cores are 1-5, 45-80 and 25-45\%, respectively, while the mean grain size is silt in every layer (Fig. 4). Statistical grain-size parameters (standard deviation, skewness, kurtosis) calculated by Folk and Ward's (1957) formulas indicate that the whole sediments are well-sorted and very-well-sorted $(\sigma<40 \varphi)$, and grain distributions are fairly symmetric (skewness is between +0.11 and -0.9 ). The size distributions of nearly all sediment samples are mesokurtic $(\mathrm{K}=0.95-1.18)$, indicating a symmetric distribution of sorting. The mineralogical composition of the silt-size grains of the lake sediment mainly consists of quartz (35-85\%), feldspar (10-35\%) and calcite (10-30\%). Clay-size particles are mainly composed of smectite (57-98\%), kaolinite (6-28\%) and, to a lesser extent, illite (3-20\%). The volume weight or wet bulk density of the lacustrine sediment varies between 1.260 and $1.345 \mathrm{~g} \mathrm{~cm}^{3}$ and the average is $1.304 \mathrm{~g} \mathrm{~cm}^{3}$.

Loss-on-Ignition (LOI) analyses at 10-cm intervals in core AK02LV10 indicate variations from 1 to $7 \%$ organic matter and 2 to $10 \%$ carbonates (Fig. 7). The organic matter increases at depths of 6-5 m, 3-2 m and 1-0.25 m. Carbonate content increases when organic matter decreases and both are independent of grain size (Fig. 7). The relatively high carbonate content of Lake Ulubat may come from erosion of the Mesozoic limestones in the drainage basin and from karstic springs originating in the limestone. 
Sediment ages and the age-depth model of Lake Ulubat core AK02LV11 were based on results of ${ }^{137} \mathrm{Cs},{ }^{210} \mathrm{~Pb}$ and ${ }^{14} \mathrm{C}$ dating methods (Fig. 2) and are given in Kazanc1 et al. (2006). For the uppermost half-meter of the core $(0-45 \mathrm{~cm})$ collected from the delta front, radionuclides yielded sedimentation rates of about $1.79 \mathrm{~cm} \mathrm{yr}^{-1}\left({ }^{14} \mathrm{C}\right), 1.48 \mathrm{~cm} \mathrm{yr}^{-1}\left({ }^{137} \mathrm{Cs}\right)$, and $1.6 \mathrm{~cm} \mathrm{yr}^{-1}$ $\left({ }^{210} \mathrm{~Pb}\right)$. For the last century, the mean sedimentation rate in Lake Ulubat has been approximately $1.6 \mathrm{~cm} \mathrm{yr}^{-1}$. Over the entire lacustrine sequence (i.e. the last $\sim 16$ centuries), however, it has been $\sim 0.37 \mathrm{~cm} \mathrm{yr}^{-1}$ (Kazanc1 et al. 2006).

Profiles of only a few elements in the lake sediment are presented in this study. They are Al, $\mathrm{Ba}, \mathrm{Cu}, \mathrm{Fe}, \mathrm{Mn}, \mathrm{Ni}, \mathrm{Pb}, \mathrm{Hg}, \mathrm{As}$, and $\mathrm{B}$, most of which are heavy metals and strong pollutants of the environment (EPA 1973). The primary and/or main sources of all heavy metals in sediments are ore deposits, particularly those that are being actively mined, and industrial activities (Horowitz et al. 1995; Larsen 2000; Ek and Renberg 2001; Blake et al. 2007). There are mining and industrial sources in the drainage area of Lake Ulubat (two active boron mines, two active lignite mines and a thermal power plant) (Fig. 1). In Figure 7, the abundances of the heavy elements in sediment cores AK02LV10 and AK02PVC4 are shown. Values greatly exceed the accepted limit for flowing water and lake water (Tables 3-5) (i.e. $50 \mathrm{ppb}$ for $\mathrm{Pb}$ and $\mathrm{Cu}$; EPA 1973). On average, $\mathrm{Fe}$ is $39,770 \mathrm{ppm}, \mathrm{Al}$ is $68,210 \mathrm{ppm}, \mathrm{Mn}$ is $450 \mathrm{ppm}, \mathrm{Cu}$ is $65 \mathrm{ppm}, \mathrm{Ni}$ is 350 ppm, $\mathrm{Ba}$ is 4,890 ppm, $\mathrm{Pb}$ is $110 \mathrm{ppm}, \mathrm{Hg}$ is $1.20 \mathrm{ppm}$, and $\mathrm{As}$ is $1.03 \mathrm{ppm}$ in the sediment of Lake Ulubat. Concentrations of the elements over the lengths of the cores vary little (Fig. 7). However, the values of $\mathrm{As}$ and $\mathrm{Hg}$ increase slightly in younger sediments, probably due to anthropogenic influences. Typically, groups of heavy metals increase or decrease together at the same levels (Fig. 7). This is probably a consequence of element chemistry because the amount of some heavy metals is controlled by organic matter (Lin and Chen 1998; Muller et al. 2001).

A rough relationship between grain-size and element concentration is also seen for some heavy metals within the Lake Ulubat sediment (Fig. 8). Fe, Al, Mn, $\mathrm{Ni}$ and to some extent $\mathrm{Pb}$ are relatively high in finer sediment (Fig. 8). In general, heavy metals increase when clay-size particles dominate in a lacustrine system (Muller et al. 2001). The present-day relationships among elements, sediment load and water discharge show that sediments and associated heavy metals have been transported to Lake Ulubat in suspension mainly in the summer and autumn months (Fig. 5). The mountainous drainage area and large difference in elevation between the lake and sources (Fig. 1) may enable continual element transportation, even when water discharge is very low in summer months (Table 5). 
A prominent characteristic of the Lake Ulubat sediment is the high boron content, with average concentrations of 1205 and 206 ppm in sediment cores AK02LV10 and AK02PVC from the western and eastern parts of the eastern lake basin, respectively (Fig. 2). These values greatly exceed the limit for natural aquatic environments, which is $0.2 \mathrm{ppm}$ (EPA 1973). The boron content in the sediment sequence increases sharply at the 4-m level (Fig. 7). This may be a result of possible exposure of borate beds in the catchment by natural erosion ca. 1000 years ago (Kazanc1 et al. 2006) (Table 5).

\section{Tank experiment}

The aim of the simple tank experiment was to simulate sediment resuspension and removal via an outlet, similar to the situation in Lake Ulubat. There was an obvious sediment-size difference between the medium-size, silt-dominated sediment sequence (Figs. 4 and 7) and the discharge of a high-volume, clay-dominated suspended load into the lake via the MKP River (EIE 2000). The windy climate may account for this. We hypothesize that wave energy keeps suspended particles in the water column for a long time. This would provide time for the particles to reach the outlet in suspension. Similar results were obtained in previous experiments that used not only finegrained particles, but also plankton (Brander et al. 1993; Reimnitz et al. 1993). Dethleff and Kempema (2007) recently showed that fine sediment particles could be resuspended and preferentially incorporated into ice as a consequence of Langmuir circulation. Bachman et al. (2000) also discuss wave effects on sediment resuspension in shallow lakes.

Our results showed that the amount of clay-size particles in the sediment decreased up to 8$15 \%$ in each experiment, but was never $<8 \%$ (Table 6). The most important variable for resuspension and removal of fine particles was depth of the water column, with the shallowest level $(2 \mathrm{~cm})$ providing the largest result. The clay content of the "sorted" deposits in the tank was 8.3\% (Table 6). Other important variables that influence sediment transport may include the amount of outfow water and the fan speed (i.e. wave energy), but they were not tested, being beyond the scope of this study.

\section{Discussion}

Lake Ulubat has received sediments, water, and pollutants from a large drainage basin (SDB), occupied partly by forests, but mostly by farmlands . Possible sources of heavy metals are: a) soil erosion and soil particulates delivered to the lake, b) mining and other industrial activities, c) agricultural practices, and d) waste disposal from large villages and towns (Çelenli 2000; Toprak 
2004; Dalkiran et al. 2006). Concentrations of heavy metals and other pollutants in the lake change with the seasons (EIE 1993), probably due to seasonal tree cutting, ploughing, flooding, storms and mining (Tables 2 and 3; Figs. 3, 5, and 6).

Some heavy metals and the boron content of the sediment sequence of Lake Ulubat were described in detail. Their distributions throughout the sequence are more or less uniform, except for a sharp increase in boron content at the 4-m level (Fig. 7). Also, the mean grain size of the lacustrine sediment, excluding the intervals $2-2.5 \mathrm{~m}$ and $6-6.5 \mathrm{~m}$, remains similar, medium-tofine silt. Organic matter and carbonate content, however, do not show constant concentrations (Figs. 4, 7 and 8). The heavy metals and grain-size data indicate that source rocks in SDB produced and delivered the particles and elements to the lake as if environmental conditions were stable during the entire time of deposition (Figs. 7-9; Table 5). Such a uniform distribution of heavy element in sediment sequence is only possible while mining wastes are source of sediments (i.e. Horowitz et al. 1995; Blake et al. 2007). A recent study showed that the transport of heavy metals was controlled by the duration of leaching together with element associations in wet to very wet climatic conditions (Liu et al. 2006). An abundance of heavy metals in lake sediments could be related to montmorillonite-dominated mineral composition, and sometimes to the discharge of hydrothermal water into the basin (e.g. Bilali et al. 2002). Besides, the irregular and/or partly cyclic distribution of organic matter and carbonate content in the sediment (Fig. 7) indicates a climatic control on deposition (Shuman 2003). Historic climate changes in NW Anatolia are mentioned in local and regional literature (Brice 1978; Heim et al. 1997; Eastwood et al. 1999; Roberts et al. 1997; 2001; Bottema et al. 2001; Kazanc1 et al. 2004; Mudie et al. 2007).

The unexpected heavy metal distributions in this study are possibly a consequence of hydrological conditions and water movements in Lake Ulubat, which are affected by seasonal winds. Lake Ulubat is a shallow, fresh-water reservoir with a large outlet. Its water level has fluctuated seasonally in response to precipitation and meltwater inputs (Figs. 2 and 3). On windy days, the water may take on a yellowish-grey color because of high abundance of suspended sediments in the water column (Kazanc1 et al. 1998). The downcore, uniform distribution of heavy metals in the sediment is likely related to this sediment resuspension (Bachman et al. 200; Douglas and Rippey 2000). Strong winds may also explain the dominance of silt in Lake Ulubat sediment (Figs. 4, 8 and 10). 


\section{Availability of heavy metals from parent rocks and industries}

Water, sediment, and the ionic load to Lake Ulubat come from the MKP River of the SDB, where the Neogene succession is exposed and some borate and lignite beds have been mined for the last 50 years (Fig. 1). Ore deposits and mines are the most important element sources for lakewater and sediment (Horowitz et al. 1995; Blake et al. 2007). Together with volcaniclastics of the Neogene succession, borate beds and even boron minerals in the SDB account for the abundant heavy metal elements in the lake. For example, analyses of 20 colemanite samples showed that the mean values of $\mathrm{Al}, \mathrm{Fe}$, and $\mathrm{Ba}$ were 973, 767, $27 \mathrm{ppm}$, and those of $\mathrm{Mn}$ and $\mathrm{Cu}$ were 22 and $27 \mathrm{ppb}$, respectively (Helvac1 1984, 1986). The water of the MKP River includes high concentrations of dissolved ions, particularly boron and heavy metal elements (EIE 1996, 2003). Our own analyses support this conclusion (Table 2). The main source of the heavy metals in the Lake Ulubat sediments is thus the borate-bearing Neogene succession. Active mines and other industrial activities have recently caused the amount of heavy metal elements in the lacustrine sediment to increase.

The heavy metal contents in the source rock, the MKP River, lake water, and the modern and older lake sediment are presented in Table 5. This comparison was made to illustrate the link between heavy metals in the source rocks and their accumulation in lacustrine sediments. The values indicate that the ratios of heavy metals in the source rocks and the river water is about 1/1.5 - 1/18, but 1/1- 1/9 from river to lake water (Fig. 9; Table 5). The concentration of elements in the modern sediments of the lake is 300-72,000 times greater than their concentration in the lake water. However, their concentrations in older sediments are 1- to $45 \%$ less than content in the modern sediments. Overall, our study shows that enrichment of heavy metals in the lake sediment with respect to the source rock is $\mathrm{Al}$ : 9x, Fe: 20x, Ba: 9x, Mn: 35,000x, Cu: 1,815x (Fig. 9; Table 5). These are relatively low values given that Lake Ulubat has received a high volume of water and allochthonous sediment since the Late Holocene. The large difference in heavy metal contents between modern and older sediments also requires explanation. We believe it is a consequence of short water residence time in the lake, controlled by water-level oscillations and the large outlet (Figs. 3, 9 and 10).

\section{Hydrology and water residence time in Lake Ulubat}

Lake Ulubat's water level fluctuates up to $3 \mathrm{~m}$. Maximum stage occurs in late March and lowest levels occur in September, in spite of a control structure on the outlet (EIE 2002) (Fig. 3). Melt 
water dictates the stage, as the lake's drainage area is large and mountainous (Fig. 1). The large water-level oscillations in this shallow lake $(\sim 2 \mathrm{~m})$ are related to changes in the seasonal discharge of the MKP River, together with summer evaporation from the lake surface. Pumping from the lake for irrigation and many groundwater wells in the surrounding area also contributed to low lake level in the summers of the last ten years. Maintaining at least moderate water level fluctuations is vital for the local ecology. The eastern basin is relatively less influenced by wind, due to a high bedrock wall in the south, which limits the wave generation in this subbasin. Hence, that area of the lake bottom is partly covered by aquatic plants that trap clayey sediments. Lake Ulubat has a large drainage basin $\left(>10,000 \mathrm{~km}^{2}\right)$, and has received $1.3 \times 10^{6}$ tons of sediment annually over the last 30 years from the MKP River. The mean linear sediment accumulation rate in Lake Ulubat has been $\sim 1.6 \mathrm{~cm} \mathrm{yr}^{-1}$ for the last 50 years (Kazanc1 et al. 2004). It was expected that such a high sediment input to the lake would have resulted in a higher net sedimentation rate. Large amounts of suspended sediment, however, were probably transported out of the lake via its outlet, which also accounts for the silt-dominated lithology of the lacustrine sequence. This process was simulated by our tank experiments (Table 6). Such transport of specific grain sizes by winnowing is not surprising in shallow lakes (Bachman et al. 2000; Douglas and Rippey 2000). Much of the heavy metal load is probably transported out of the lake with outflow waters and their suspended clayey sediments (Figs. 4, 9, 11). This discharge process probably explains the high concentrations of heavy metals in the modern sediment of the southern Marmara Sea (e.g. Algan et al. 2004).

Deposition of suspended particles from standing water in lakes requires time. Several environmental variables influence the accumulation of elements on the lake bottom, including $\mathrm{pH}$, salinity, ionic composition, water depth, water circulation, temperature, organic and inorganic matter content. The retention time of the water in the basin, however, is critical for element accumulation (Barnes and Barnes 1978; Krauskopf 1979; Langmuir 1997). Because of local climate conditions and basin morphometry, Lake Ulubat has a relatively short water residence time. Monthly hydrologic inputs to the lake and annual lake-level oscillations indicate rapid replacement of water in the lake during spring and early summer (Figs. 3 and 5). When water inflows are considered together with lake volume $\left(135 \mathrm{~km}^{2}\right.$ surface area, $2 \mathrm{~m}$ depth, discharge mean $64 \mathrm{~m}^{3} \mathrm{~s}^{-1}$, minimum $7.5 \mathrm{~m}^{3} \mathrm{~s}^{-1}$ and maximum $3374 \mathrm{~m}^{3} \mathrm{~s}^{-1}$ ), the shortest and longest lake water residence times are 22 hours (i.e. about 1 day) and 450 days, respectively. Using the mean discharge, the lake volume is replaced about every 50 days, or about seven times per year. Such rapid replacement of lake water prevents persistent stratification, or deposition of fine particles and their associated elements in reservoirs (e.g. Mian and Yanful 2004). 


\section{Wind effects on deposition of heavy metals}

The physical and chemical features of heavy metals and their behaviours under different conditions are known well (Krauskopf 1979; Langmuir 1997; Last and Smol 2001). Concentration and/or distribution of these elements in lakes interact strongly with sediment characteristics such as mineralogy, grain-size, organic matter, carbonate content, acidity, salinity and pH. (Lin and Chen 1998; Boyle 2001; Muller et al. 2001; Wolf et al. 2001; Hoffman et al. 2005). Moreover, sediment resuspension and redistribution, along with associated elements, are common in wind-stressed shallow lakes (Bachman et al. 2000; Douglas and Rippey 2000; Mian and Yanful 2004).). In Lake Ulubat, the sediment sequence displays a uniform heavy metal distribution in spite of the heterogeneity in carbonate and organic matter content (Figs. 4 and 7). The last two variables are very sensitive to climatic conditions, and thus reflect past climate changes (Meyers 2003; Shuman 2003). The uniform element distribution in the sediment sequence is related to the silt-dominated lithology, which is a consequence of sorting of the lacustrine sediment and transport of clay-size particles from the basin via the outflow. The short water residence time in Lake Ulubat contributes to this effective sediment sorting. Winds also play an important role in this process, as they are strong in winter and spring when discharges of water and sediment load into the lake are maximal (Table 5). Heavy metals are transported out of the lake along with the clay-size particles with which they are associated (Figs. 8 and 10). Tank experiments support this interpretation (Table 6). Also, high dissolved ion concentrations and the large suspended sediment load of the Kocadere River indicate the important role of the outlet in removing material from the waterbody (Fig. 5). We conclude that heavy metals have been associated with very fine particles in Lake Ulubat, and were exported from the lake, as suggested in Muller et al. (2001). The ratios of heavy metals in surface sediments relative to deeper basin fill are about 0.55-0.9x. This decrease in heavy ions in older lake deposits is explained by the resuspension and transport of fine-grain surface sediments. Interactions between the lake water and the surface sediment in Lake Ulubat are mediated by winds (Blom et al. 1992) and are responsible for the heavy metal stratigraphy in the sediment (Fig. 10).

\section{Conclusions}

Lake Ulubat (NW Turkey) is a shallow, freshwater lake in a windy, semi-arid region (Fig. 1). Its water level fluctuates annually under the influence of wet and dry seasons (Fig. 3). It receives 1.3 $\mathrm{x} 10^{6}$ ton $\mathrm{yr}^{-1}$ of suspended sediment from the Mustafakemalpaşa River, which drains a large area containing heavy metals. The mean sedimentation rate over the last $\sim 1,600$ years has been 0.37 
$\mathrm{mm} \mathrm{yr}^{-1}$, but has increased in the last century to $1.6 \mathrm{~cm} \mathrm{yr}^{-1}$. The lake sediment is silt-dominated even though the lake receives a large suspended sediment load (Fig. 4). Heavy metals display relatively constant concentrations along the entire lengths of sediment cores (Fig. 7). Some heavy metal concentrations were tracked from the source area, in river water and in lake water, to their destinations in modern and older lacustrine sediments (Tables 2-5). The transfer ratios of heavy elements from one environment to another are reasonable. They do, however, decrease between the modern surface sediments and the underlying deposits (Table 5, Fig. 9). Wind probably accounts for the relation between the silt-dominated lithology and the homogenous distributions of heavy metals within the lacustrine sequence. Wind and/or waves affected the lake surface sediments and cause winnowing of resuspended particles and associated heavy metals from the lake. This interpretation was supported by a tank experiment.

The case study of Lake Ulubat shows that the heavy metal deposition in shallow freshwater lakes is not directly controlled by climate (precipitation and temperature), as the majority of elements disappeared with fine particles just after deposition on the lake bottom. Water residence time in lakes influences grain-size and heavy metal content of sediments. Water depth and fetch, combined with windiness, exert controls on heavy metal deposition. Results obtained here may have application in tracking the fate of pollutants in many drainage basins. The area downstream of a wind-stressed lake might be especially at risk for pollutant contamination.

\section{Acknowledgements}

This study was supported mainly by the Technical and Scientific Research Council of Turkey (TUBITAK-YDABCAG 103Y102), and by NATO (EST.CLG.978645). The geological and first limnological studies were supported by a project of the National Marine Research Programme, created by joining the State Planning Organisation (DPT), TUBITAK and the General Directorate of Mineral Research and Exploration (MTA), under the coordination of Naci Görür of ITU (TUBITAK YBAG-456 and YDABÇAG-598/G). The lake coring campaign was funded by a NATO grant to SL and NK and partly by MTA. Sediment samples were analysed in the laboratories of the Gebze Institute of Technology (GYTE) and Brunel University (BU). Ö. Toprak and C. Turgut used cores taken in this project as material for their MSc thesis in GYTE. A grant from the Leverhulme Trust $(\mathrm{F} 00275 \mathrm{H})$ to SL funded a research assistant $(\mathrm{PC})$. The authors are also grateful to Prof. Cahit Helvacı (DEU) for providing literature and analytical results about the boron beds in the SDB, to Alper Gürbüz (AU) for drawing some figures and to Mr. Hüseyin Otlu (a fisherman from Gölyazı village in Lake Ulubat) for the use of his boat during sampling. We are also grateful to M. Leng (NERC), to M. Turner (Brunel University) and to G. Erpul (Ankara University) for their scientific and editorial comments. Suggestions and 
corrections of two anonymous reviewers and M. Brenner improved the paper significantly. All are acknowledged with pleasure.

\section{References}

Akyüz H.S, Semiz C (1995) The geological evolution of the vicinity of the Paşalar excavationarea, Mustafa Kemalpaşa-Bursa. J Hum Evol 28: 303-308

Algan O, Balkış N, Çağatay MN, Sarı E (2004) The sources of metal contents in the shelf sediments from the Marmara Sea, Turkey. Environ Geol 46: 932-950

Andrews P (1990) Palaeoecology of the Miocene fauna from Paşalar, Turkey. J Hum Evol 19: 569-582

Bachmann RW, Hoyer MV, Canfield Jr DE (2000) The potential for wave disturbance in shallow Florida lakes. Lake Reserv Manage 16: 281-291

Barnes MA, Barnes WC (1978) Organic Compounds. In: Lerman, A. (Ed.), Lake Sediments, Chemistry-Geology-Physics, Springer Verlag, New York, pp. 127-147

Bennett KD (2003) Psimpoll 4.10 manual. www.kv.geo.uu.se/inqua/boutique.htm

Bilali L, Rasmussen PE, Hall GEM, Fortin D (2002) Role of sediment composition in trace metal distribution in lake sediments. Appl Geochem 17: 1171-1181

Blom G, Vanduin Ehs, Aalderink Rh, Lijklema L, Toet C (1992) Modeling sediment transport in shallow lakes - interactions between sediment transport and sediment composition.

Hydrobiologia 235, 153-166

Bottema S, Woldring H, Kayan I. (2001) The Late Quaternary vegetation history of western Turkey. In: J.J. Roodenberg and L.C. Thissen (Eds.), The Ilipinar Excavations II, Nederlands Instituut Voor Het Nabije Oosten, Leiden, pp. 327-354

Boyle J (2001) Redox remobilization and the heavy metal record in lake sediments: a modelling approach. J Paleolimnol 26: 423-431

Brander KM, Milligan SP, Nichols JH (1993) Flume tank experiments to estimate the volume filtered by high speed plankton samples and to asses the effect of net clogging. J Plankton Res 15: $385-401$

Brice WC (1978) The dessication of Anatolia. In: W.C. Brice (Ed.), The Environmental History of the Near and Middle East Since the Last Ice Age, Academic Press, London, pp. 141-147

Bronk Ramsey C (2001) Development of the radiocarbon program OxCal. Radiocarbon 43: 355363

Çağatay MN, Özcan M, Güngör E (2004) Pore-water and sediment geochemistry in the Marmara Sea (Turkey): early diagenesis and diffusive fluxes. Geochem-Explor Env A: 213-225

Çelenli A (2000) Uluabat Gölü Çevre Jeokimyası. Doktora Tezi, İstanbul Teknik Üniversitesi Fen Bilimleri Enstitüsü, İstanbul, Doktora Tezi (yayınlanmamış) 
Çiçek A, Koparal AS (2004) Accumulation of sulphur and heavy metals in soils and tree leaves sampled surroundings of Tunçbilek Thermal Power Plant. Chemosphere 57: 1031-1036

Çolak M, Helvacı C, Maggetti M (2000) Saponite from the Emet colemanite mines, Kütahya, Turkey. Clay Clay Miner 48: 409-423

Dalkıran N, Karacaoğlu D, Dere S, Şenturk E, Torunoğlu T (2006) Factors affecting the current status of a eutrophic shallow lake (Lake Uluabat, Turkey): Relationships between water physical and chemical variables. J Chem Ecol 22: 279-298

Dethleff D, Kempema EW (2007) Langmuir circulation driving sediment entrainment into newly formed ice; tank experiment results with application to nature (Lake Hatte, United States, Kara Sea, Siberia). J Geophys Res 112: C02004, doi: 10.1029/2005JC003259

Douglas RW, Rippey B (2000) The random redistribution of sediment by wind in a lake. Limnol Oceanogr 45: 686-694

Dündar C, Canbaz M, Akgün N, Ural G (2002) Türkiye Rüzgar Atlası. Devlet Meteoroloji İşleri Genel Müdürlüğü Yayınları, no 2002/04, Ankara

Eastwood WJ, Roberts CN, Lamb HF, Tibby JC (1999). Holocene environmental change in southwest Turkey; a palaeoecological record of lake and catchment-related changes. Quaternary Sci Rev 18: 671-695

EIE (1996) Türkiye Akarsularinda Su Kalitesi Gözlemleri. Elektrik İşleri Genel Müdürlüğü, Ankara, Yayın no 96-4

EIE (2000) Türkiye Akarsularinda Suspanse Sediment Gozlemleri ve Sediment Tasinim Miktarları. Elektrik İşleri Genel Müdürlüğü, Ankara, yayın no 20-17

EIE (2002) Türkiye Göl Seviyeleri. Elektrik İşleri Genel Müdürlüğü, Ankara, yayın no 02-13

EIE (2003) Türkiye Akarsularında Su kalites Gözlemleri (Water Quality Data for Surface Water in Turkey). Elektrik İşleri Genel Müdürlüğü, Ankara, yayın no 03-14-28

Ek AS, Renberg I (2001) Heavy metal pollution and lake acidity changes caused by one thousand years of copper mining at Falun, central Sweden. J Paleolimnol 26: 89-107

Emre Ö, Erkal T, Kazancı N, Görmüş S, Görür N, Kuşçu I (1997a) Guney Marmara'nin Neojen ve Kuvaterner' deki morfotektonigi. İç: Güney Marmara Bolgesinin Neojen ve Kuvaterner Evrimi. Türkiye Bilimsel ve Teknolojik Araştırma Kurumu Raporu, Proje no YDABCAG426/G, Ankara, p YDABCAG-426/G, Ankara, p. 36-68

Emre Ö, Erkal T, Tchepalyga A, Kazancı N, Keçer M, Ünay E (1998) Neogene-Quaternary evolution of the eastern Marmara region, Northwest Turkey. Bulletin of Mineral Research and Exploration Institute 120, 119-145

Emre Ö, Kazancı N, Erkal T, Karabıyıkoglu M, Kuşçu I (1997b) Ulubat ve Manyas göllerinin oluşumu ve yerleşim tarihcesi. İç: Güney Marmara Bolgesinin Neojen ve Kuvaterner Evrimi. Türkiye Bilimsel ve Teknolojik Araştırma Kurumu Raporu, Proje no YDABCAG-426/G, Ankara, p YDABCAG-426/G, Ankara, p. 116-134 
Engstrom DR, Wright HE Jr (1984) Chemical stratigraphy of lake sediments as a record of environmental change. In: Haworth, E.Y. and Lund, J.W.G. (Eds) Lake Sediments and Environmental History, Leicester University Press, Bath, p. 11-68

EPA (Environment Protection Agency) (1973) Methods for Identifying and Evaluating the Nature and Extent of Non-point Sources of Pollutants. Publ. EPA 430/9-73-014, Washington D.C., USA

Folk RL, Ward WC 1957 Brazos River bar: a study in the significance of grain size parameters. J Sediment Petrol 27: 3-26

Görür N, Sakınç M, Barka A, Akkök R, Ersoy Ş (1995) Miocene to Pliocene palaeogeographic evolution of Turkey and its surroundings. J Hum Evol 28: 309-324

Griffiths JC, 1967. Scientific Method in Analysis of Sediments. McGraw-Hill, New York, N. Y., 508

Heim C, Nowaczyk N, Negendank J, Leroy S, Ben-Avraham Z (1997) Middle-East desertification: evidence from the Dead Sea. Naturwissenschaften 84: 398-401

Helvac1 C (1984) Occurrence of rare borate minerals: veatchite-A, tunnellite, terrugite and cahnite in the Emet borate deposits, Turkey. Miner Deposita 19: 217-226

Helvac1 C (1986) Geochemistry and origin of the Emet borate deposits, western Turkey. Bulletin of the Faculty of Engineering, Cumhuriyet University, Serie A- Earth sciences 3, 49-73

Helvacı C, Firman RJ (1977) Emet borat yataklarının jeolojik konumu ve mineralojisi. Jeoloji Mühendisliği Dergisi 2, 17-28

Hofmann P, Duckensell M, Chpitsglous A, Schwark L (2005) Geochemical and organic petrological characterization of the organic matter of lacustrine Eocene oil shales (Prinz von Hessen, Germany): reconstruction of the depositional environment. J Paleolimnol 33: 155 - 168

Horowitz AJ, Elrick KA, Robbins JA, Cook RB (1995) A summary of the effects of mining and related activities on the sediment-trace elements geochemistry of Lake Coeur d'Alene, Idaho, USA. J Geochem Explor 52: 135-144

Kazancı N, Bayhan E, Suliman N, Sahbaz A, Ileri Ö, Özdogan M, Temel A, Ekmekçi M (1997) Manyas Gölü ve Güncel tortullari. İç: Güney Marmara Bolgesinin Neojen ve Kuvaterner Evrimi. Türkiye Bilimsel ve Teknolojik Araştırma Kurumu Raporu, Proje no YDABCAG-426/G, Ankara, p. 192-238

Kazancı N, Ileri O, Suliman N, Özdoğan M, Bayhan E, Şahbaz A, Gencer A, Ergin M, Erkmen C (1998) Ulubat Gölü'nde güncel tortullaşma. İç: Marmara Denizi Güneyi Kıyı ve Kıyı Ardı Istiflerinin Stratigrafisi, Sedimantolojisi ve Morfotektonigi. Türkiye Bilimsel ve Teknolojik Araştırma Kurumu Raporu, Proje no YDABCAG - 598/G, p. 99 - 145

Kazanc1 N, Leroy SAG, Ileri O, Emre O, Kibar M, Öncel S (2004) Late Holocene erosion in NW Anatolia from sediments of Lake Manyas, Lake Ulubat and the southern shelf of the Marmara Sea, Turkey. Catena 57: 277-308 
Kazancı N, Toprak Ö, Leroy SAG, Öncel S, Ileri Ö, Emre Ö, Costa P, Erturaç K, McGee E (2006) Boron content of Lake Ulubat sediment: a key to interpret the morphological history of NW Anatolia, Turkey. Appl Geochem 21: 234-251

Kirby ME, Poulsen CJ, Lund SP, Patterson W, Reidy L, Hammond DE (2004) Late Holocene lake level dynamics inferred from magnetic susceptibility and stable oxygen isotope data: Lake Elsinore, southern California (USA). J Paleolimnol 31: 275-293

Koçman A (1993) Türkiye iklimi. Ege Universitesi , Izmir

Krauskopf K (1979) Introduction to Geochemistry. McGraw Hill, NY

Kuniholm PI (1990) Archaeological evidence and non- evidence for climatic change. In: S. J. Runcorn and J.-C. Pecker, Eds. The Earth's Climate and Variability of the Sun Over Recent Millennia, Phil. Trans. R. Soc. Lond., pp. 645-655

Langmuir D (1997) Aqueous Environmental Geochemistry, Prentice Hall, NY

Larsen J (2000) Recent changes in diatom-inferred pH, heavy metals, and spheroidal carbonaceous particles in lake sediments near an oil refinery at Mongstad, Western Norway.

J Paleolimnol 23: 343 - 363

Last WM, Smol JP (Eds) (2001) Tracking Environmental Change Using Lake sediments. Volume 2: Physical and Chemical Techniques. Kluwer Academic Publishing House, Dordrecht, The Netherlands

Leroy SAG, Kazanc1 N, Ileri Ö, Kibar M, Emre O, McGee E, Griffiths HI (2002) Abrupt environmental changes within a late Holocene lacustrine sequence south of the Marmara Sea (Lake Manyas, N-W Turkey). Mar Geol 190: 531-552

Lin J-G, Chen S (1998) The relationship between adsorption of heavy metal and organic matter in river sediments. Environ Int 24: 345-352

Liu CL, Chang TW, Wang MKT, Huang TCH (2006) Transport of cadmium, nickel, and zinc in Taoyuan red soil using one-dimensional convective-dispersive model. Geoderma 131: 181-189

Meyers PA (2003) Applications of organic geochemistry to paleolimnological reconstructions: a summary of example from the Laurentian Great Lakes. Org Geochem 34, 261-289

Mian MH, Yanful EK (2004) Analysis of wind-driven resuspension of metal mine sludge in a tailings pond. J Environ Eng Sci 3: 119-135

Mudie PJ, Marret F, Aksu AE, Hiscott R. Gillespie NH (2007) Palynological evidence for climatic change, anthropogenic activity and outflow of Black Sea water during the late Pleistocene and Holocene: Centennial- to decadal-scale records from the Black and Marmara Seas. Quatern Int 167/168: 73-90

Muller G, Ottenstein R, Yahya A (2001) Standardized particle size for monitoring, inventory and assessment of metals and other trace elements in sediments. Fresen J Anal Chem 371: 637-642

Muri G, Wakeham SG, Pease TK, Faganeli J (2004) Evaluation of lipid biomarkers as indicators of changes in organic matter delivery to sediments from Lake Planina, a remote mountain lake in NW Slovenia. Org Geochem 35: 1083-1093 
Okay AI, Siyako M, Burkan KA (1991) Biga Yarimadasinin jeolojisi ve tektonik evrimi. Türkiye Petrol Jeologlari Dernegi Bulteni 2: 83-121

Özdemir DA, Kırmızıgül H (1997) 1996 Y1lı Türkiye Iklimi. Devlet Meteoroloji Isleri Genel Mudurlugu, Ankara

Reimnitz E, Clayton JR, Kempema EW, Payne JR, Weber WS (1993) Interaction of rising frazil with suspended particles: tank experiments with applications to nature.

Cold Reg Sci Technol 21: 117-135

Roberts CN, Eastwood WJ, Lamb HF, Tibby JC (1997) The age and causes of Mid-Late Holocene environmental change in southwest Turkey. In: Dalfes N.Z., Kukla G. \& Weiss H. (Eds), Third Millennium BC Climate Change and Old World Collapse, NATO ASI Series vol. 49, Springer-Verlag, Berlin, Heidelberg, pp. 409-429

Roberts CN, Reed JM, Leng MJ, Kuzucuoglu C, Fontugne M, Bertaux J, Woldring H, Bottema S, Black S, Hunt E, Karabiyikoglu M (2001) The tempo of Holocene climatic change in the eastern Mediterranean region: new high-resolution crater-lake sediment data from central Turkey. Holocene 11: 721-736

Shuman B (2003) Controls on loss-on-ignition variation in cores from two shallow lakes in the northeastern United States. J Paleolimnol 30: 371-385

Stuiver M, Reimer PJ, Bard E, Beck JW, Burr GS, Hughen KA, Kromer B, McCormac G, van der Plicht J, Spurk M (1998) INTCAL98 Radiocarbon Age Calibration, 24000-0 cal BP. Radiocarbon 40: 1041-1083

Suliman N (1998) Manyas Gölündeki Güncel Tortullaşmanın İncelenmesi. Yüksek Lisans Tezi, Ankara Universitesi Fen Bilimleri Enstitüsü, Ankara, 77 p

Toprak Ö (2004) Ulubat Gölü tortullarının organik madde ve ağır metal içeriği. Yüksek Lisans Tezi, Gebze Yüksek Teknoloji Enstitüsü, Gebze, Kocaeli, 117 p

Turgut C (2005) Ulubat Gölü çökellerinde ve göl suyunda metal konsantrasyonlarının incelenmesi. Yüksek Lisans Tezi, Gebze Yuksek Teknoloji Enstitüsü, Gebze, Kocaeli, 92 p

Vermoere M, Van Thuyne T, Six S, Vanhecke L, Waelkens M, Paulissen E, Smets E (2002) Late Holocene local vegetation dynamics in the marsh of Gravgaz (southwest Turkey).

J Paleolimnol 27: 429-451

Wolf BB, Edwards TWD, Elgood RC, Beuning KR (2001) Carbon and oxygene isotope analysis of lake sediment cellulose; methods and applications. In: W.M. Last and J.P. Smol (Eds), Tracking Environmental Change Using Lake sediments. Volume 2: Physical and Chemical Techniques. Kluwer Academic Pub., Dordrecht, The Netherlands

Yalçınkaya S, Avşar ÖP (1980) Mustafakemalpaşa (Bursa) dolayının jeolojisi. MTA Raporu Derleme no: 6717, Ankara (yayınlanmamış)

Yılmaz Y, Gürpınar O, Genç SC, Bozcu M, Yılmaz K, Şeker H, Yiğitbaş E, Keskin M (1990) Armutlu Yarımadası ve civarının jeolojisi. Türkiye Petrolleri Anonim Ortaklığı (TPAO) raporu, no 2796, 210 p, Ankara (yayınlanmamış) 


\section{Figure Captions}

Fig. 1 (A) Location of Lake Ulubat and the Susurluk Drainage Basin (SDB). The symbol in (B) for borate beds (a part of source rocks) is not to scale. (C) shows the main wind directions of the Marmara region and their Turkish names

Fig. 2 Sediment sampling sites in Lake Ulubat. Cores AK02LV10 and AK02LV12 are both at station 11 and AK02PVC4 is from station 2. See Table 2 for sites of bottom water samples. The lake surface areas at different times are from air photos of 1974, 1986, and 2004. Some ages are based on sedimentation rate in the lake. See Kazanc1 et al (2006) for details of dates

Fig. 3 Water level fluctuations of Lake Ulubat from 1961 to 2004. Measurements for the last three years were provided by EIE's archives in 2006, while others are from EIE (2002). Note that there are 8-11-year cycles probably representing dry and wet periods of the region

Fig. 4 Sand, silt and clay content of core AK02LV10 (A) and the first meter of core AK02PVC4 (B). Note that some of sand content is due to macrofossil fragments. Compare with Fig. 7 for mean grain size and ionic content

Fig. 5 Monthly average of water discharge, suspended sediment, total ion concentration and boron content of the Kocasu River based on measurements from the last 30 years at EIE Observatory Station 317 (J January, F February, etc.). See Fig. 1 for location of EIE observatory

Fig. 6 Heavy metals, As and B distributions in surface water $(0-10 \mathrm{~cm})$ of Lake Ulubat. See text for sampling sites and methods. Note that the geometry of the lake is slightly deformed because of the computer techniques used (Surfer)

Fig. 7 Some element concentrations in sediments of core AK02LV10 (A) and AK02PVC4 (B) of Lake Ulubat associated with mean grain size, carbonate content and organic matter. See

${ }^{14} \mathrm{C}$ dates at the right end of A. Compare them with grain-size distribution in Fig. 4

Fig. 8 Relationships of different heavy metals and mean grain size in sediments of cores AK02LV10 and AK02PVC

Fig. 9 Transfer ratios and/or relative enrichments of some heavy metals ( $\mathrm{Al}, \mathrm{Fe}, \mathrm{Mn}, \mathrm{Cu}, \mathrm{Ba}$ ) from source rocks to lacustrine sequence in the Susurluk Drainage basin. The values were produced from Table 6

Fig. 10 Possible models of heavy metal and suspended sediment deposition in shallow lake environments; a) elements increase from surface to lake bottom in calm water conditions, b) distribution of elements is uniform in water column during windy times, even though quantity decreases due to discharges from outlet 
